\title{
Pemanfaatan Sampah Bahan Habis Pakai Non-Medis Laboratorium Ketrampilan Klinik (SKILLS LAB) Sebagai Modifikasi Alat Peraga Sederhana Skill Mandiri
}

\author{
Patmawati $^{\text {a }}$, Fadilah Hidayati ${ }^{\text {b }}$ \\ ${ }^{a}$ Laboratorium Biomedik Fakultas Kedokteran Universitas Muhammadiyah Malang \\ E-mail : patma@umm.ac.id \\ ${ }^{b}$ Laboratorium Ketrampilan Klinik FK Universitas Muhammadiyah Malang \\ E-mail : fadilahwinarno@gmail.com \\ Received: $2^{\text {nd }}$ June 2020; Revised: $8^{\text {th }}$ July 2020; Accepted: $29^{\text {th }}$ July 2010; \\ Available online: $22^{\text {th }}$ July 2020; Published regularly: July 2020
}

\begin{abstract}
The Skills Lab is a facility where students can practice the skills they need, which is not a real context between doctor and patient. Practicum in the Clinical Skills Laboratory and OSCE uses non-infectious non-medical consumables. The stages of making modification props are carried out in several stages including: collecting and sorting non-infectious non-medical consumables. Disinfection of non-medical consumables that are non-infectious with antiseptics. The produced props include gloves used as prepuce in circumcision beads. Modified infusion plastic bottles resemble human nails we use for nail extraction skills. The IV line can be modified as a vein in the bead, this is used for the sexy vein skill in the beaded IV. Abocart needle (neddle) is used for NGT or usually called sonde for experimental animals. Rubber infusion hose is used as an LED tube rubber ball in Clinical Pathology practicum.
\end{abstract}

Key Words : skills lab, non-infeksius, modifikasi, osce

\begin{abstract}
Abstrak
Laboratorium ketrampilan Klinik (Skill's Lab) adalah suatu fasilitas tempat mahasiswa dapat berlatih ketrampilan yang mereka perlukan, dimana bukan merupakan suatu konteks nyata antara dokter-pasien. Praktikum di Laboratorium Ketrampilan Klinik dan OSCE menggunakan bahan habis pakai non-medis yang bersifat noninfeksius .Tahapan pembuatan alat peraga modifkasi dilakukan beberapa tahapan diantaranya : mengumpulkan dan memilah sampah bahan habis pakai non-medis yang bersifat non-infeksius. Desinfeksi sampah bahan habis pakai non-medis yang bersifat non-infeksius dengan antiseptik. Alat peraga yang dihasilkan antara lain gloves dimanfaatkan sebagai preputium di manikin sirkumsisi. Botol plastik infus dimodifikasi menyerupai kuku manusia kita gunakan untuk skill ekstraksi kuku. Selang infus (IV Line) dapat kita modifikasi sebagai pembuluh darah pada manikin, ini digunakan untuk skill vena seksi pada manikin infus. Jarum abocart (neddle) digunakan untuk NGT atau biasanya di sebut sonde untuk hewan coba, Karet selang infus digunakan sebagai bola karet tabung LED pada praktikum Patologi Klinik.
\end{abstract}

Kata Kunci : skills lab, non-infeksius, modifikasi, osce. 


\section{PENDAHULUAN}

Laboratorium ketrampilan Klinik (Skill's Lab) adalah suatu fasilitas tempat mahasiswa dapat berlatih ketrampilan yang mereka perlukan, dimana bukan merupakan suatu konteks nyata antara dokterpasien. Akan tetapi terdapat beberapa kelebihan berlatih ketrampilan di Skill's Lab, antara lain latihan dapat dilaksanakan setelah teori diberikan sehingga dapat membantu proses belajar mahasiswa. .(Nurini.,dkk 2002)

Dalam proses pembelajaran ketrampilan klinik (Skill's Lab) sudah barang tentu banyak menggunakan alat dan bahan untuk sarana pembelajaran. Laboratorium keterampilan klinik dilengkapi sarana dan prasarana yang mendukung keterlaksanaan dan kelancaran kegiatan keterampilan klinik. Semisal kompetensi resusitasi cairan dimana membutuhkan manekin tangan dan beberapa BHP kebutuhan pemasangan infus ( contoh IV line, IV catheter, cairan infus, kapas, kassa, dll).

Praktikum di Lab. Ketrampilan Klinik dan OSCE menggunakan bahan habis pakai non-medis yang bersifat non-infeksius sehingga memungkinkan menumpuk sampah bahan habis pakai (BHP). Dikatakan bahan habis pakai non-medis bersifat non-infeksius dikarenakan selama ini penggunaan tidak pernah dilakukan pada orang langsung, semua dilakukan pada alat peraga yang dinamakan manekin. Kebanyakan kegiatan proses belajar di lab. Ketrampilan Klinik (Skill's Lab) menggunakan bahan habis pakai nonmedis pada manekin, ada juga pemeriksaan fisik dilakukan langsung kepada antar mahasiswa itu sendiri (probandus), dll. Selain pembelajaran wajib mahasiswa diberikan kesempatan untuk mngulang pembelajaran skillnya di Lab. Mandiri. Tentun bahan habis pakai di Lab. Mandiri tidak sebanyak persediaannya ketika mahasiswa skill wajib.

Skill mandiri adalah praktikum mandiri yang dilakukan oleh mahasiswa di dampingi oleh asisten dosen bertujuan untuk mengulang materi yang telah disampaikan terlebih dahulu oleh instruktur dan pakar. Pelaksanaan Skill mandiri dilaksanakan di luar jam skill utama. Tujuan skill/ praktikum mandiri ini mempunyai banyak manfaat dintaranya yaitu meningkatkan softskill mahasiswa sesuai dengan kompetensi dokter umum serta mempersiapkan ketrampilan mahasiswa menghadapi ujian ketrampilan OSCE di akhir Blok serta meningkatkan kepercayaan diri bagi mahasiswa itu sendiri.

Sebagai sarana pembelajaran Skill mandiri juga memerlukan alat dan bahan habis pakai. Manekin sebagai media latihan di ketrampilan / Skill's Lab, selama ini identik dengan harga yang lumayan mahal dan bersifat mudah rusak terutama jika dengan beban pemakaian terhadap manekin tersebut tinggi, sehingga diperlukan tambahan memodifikasi manekin untuk pembelajaran yang sifatnya mandiri dengan menggunakan bahan-bahan bekas dari kegiatan skill wajib yang sudah tidak digunakan atau bisa dibilang sampah non-infeksius dan tentunya bahan tersebut didapat dari proses pemilahan yang masih bisa dimanfaatkan dan tidak berbahaya.

Dengan menggunakan media belajar ketrampilan klinik dari limbah sampah non medis harapannya dapat mengurangi sampah non infeksius bahan habis pakai yang ada di Laboratorium Ketrampilan Klinik (Skill Labs) serta efisiensi dalam pengadaan alat \& bahan di Laboratorium Ketrampilan Klinik Fakultas Kedokteran Universitas Muhammadiyah Malang.

\section{BAHAN DAN METODE}

Bahan yang dipakai adalah sampah bahan habis pakai non-medis yang bersifat non-infeksius, sebelumnya desinfeksi sampah bahan habis pakai non-medis yang bersifat non-infeksius dengan disinfektan, sampah bahan habis pakai non-medis yang bersifat non-infeksius. Penelitian ini dilakukan di Laboratorium Biomedik Fakultas Kedokteran Universitas Muhammadiyah Malang 


\section{HASIL DAN PEMBAHASAN}

Langkah awal adalah dengan mengumpulkan dan memilah sampah bahan habis pakai non-medis yang bersifat non-infeksius Botol plastik infus bekas atau yang sudah habis dipakai, Glove / sarung tangan bekas pakai, Limbah tajam berupa IV Catheter, Spuit bekas, Selang Infus

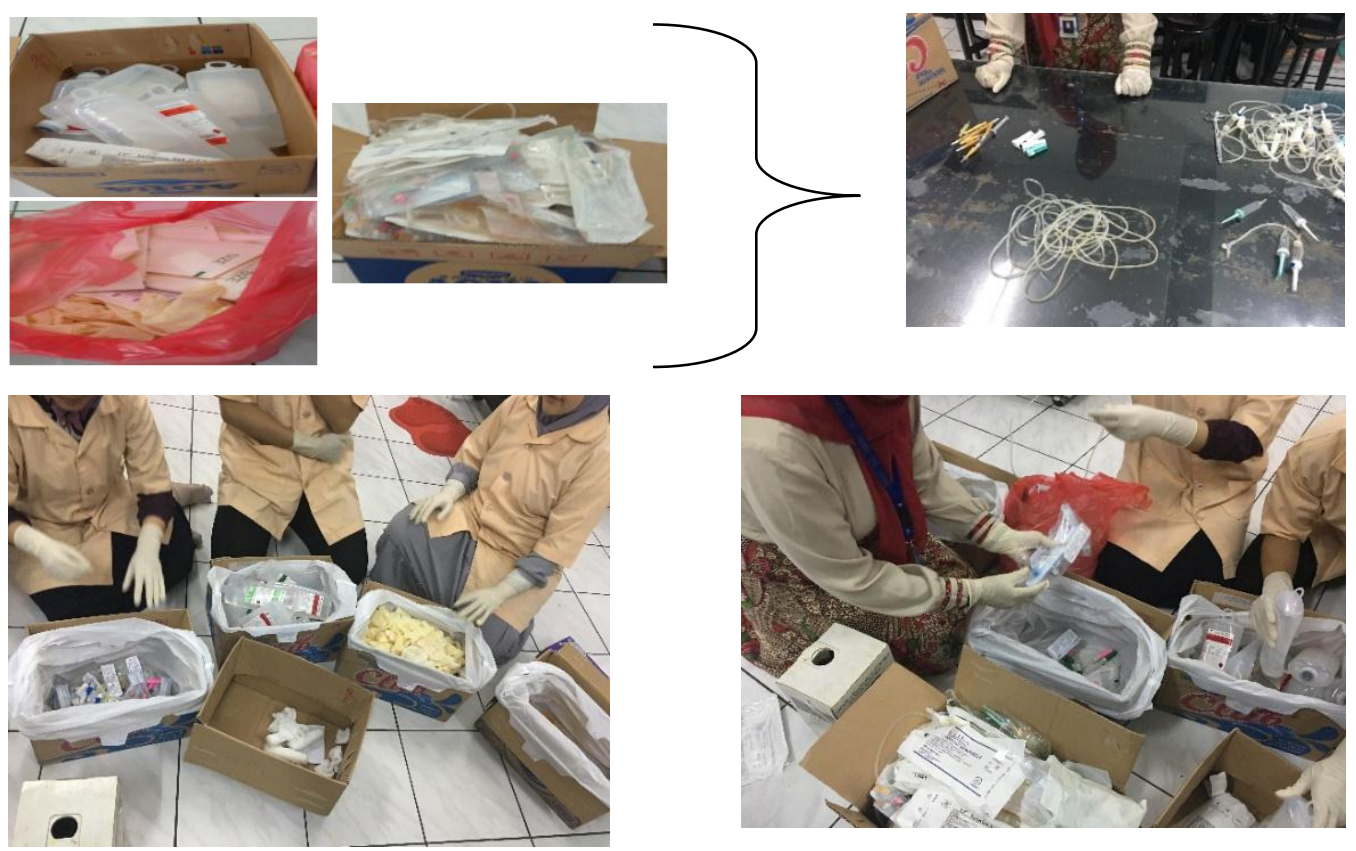

Gambar 1. Proses pemilahan sampah bahan habis pakai

Selanjutnya adalah desinfeksi sampah bahan habis pakai non-medis yang bersifat non-infeksius dengan disinfektan, dikarenakan bahan yang akan diproses bersifat bahan bekas atau sampah perlu dilakukan pencucian dengan air bersih mengalir serta di desinfeksi untuk menurunkan kemungkinan bahaya yang bisa ditimbulkan seperti jamur atau mikroba lainnya. Sebelum dilakukan desinfeksi, penting untuk membersihkan alat-alat tersebut dari debris organik dan bahan-bahan berminyak karena dapat menghambat proses desinfeksi.(Signaterdadie,2009) Disinfektan digunakan untuk membunuh mikroorganisme pada benda mati \& desinfeksi adalah membunuh mikroorganisme penyebab penyakit dengan bahan kimia atau secara fisik hal ini dapat mengurangi kemungkinan terjadinya infeksi dengan jalan membunuh mikroorganisme yang bersifat patogen. Kita siapkan klorin 5\% untuk proses desinfeksi sesuai ketentuan, dapat digunakan secara tepat guna serta aman dalam pemakaian.

Langkah selanjutnya memodifikasi sampah bahan habis pakai non-medis yang bersifat noninfeksius Pada dasarnya sampah bahan habis pakai tersebut mudah dalam memofikasinya, hanya membutuhkan kesabaran, kreatifitas dan ketelatenaan dalam pengolahannya. Proses ini membutuhkan kreasi dan ketrampilan untuk memproduksinya. Hal sederhana yang kita lakukan adalah memotong gloves atau sarung tangan sesuai dengan bentuk yang diinginkan menyesuaikan kebutuhan dari manekin yang akan gunakan. Memotong botol plastik bekas cairan infus dibentuk menyerupai kuku dan bahanbahan lainnya. 

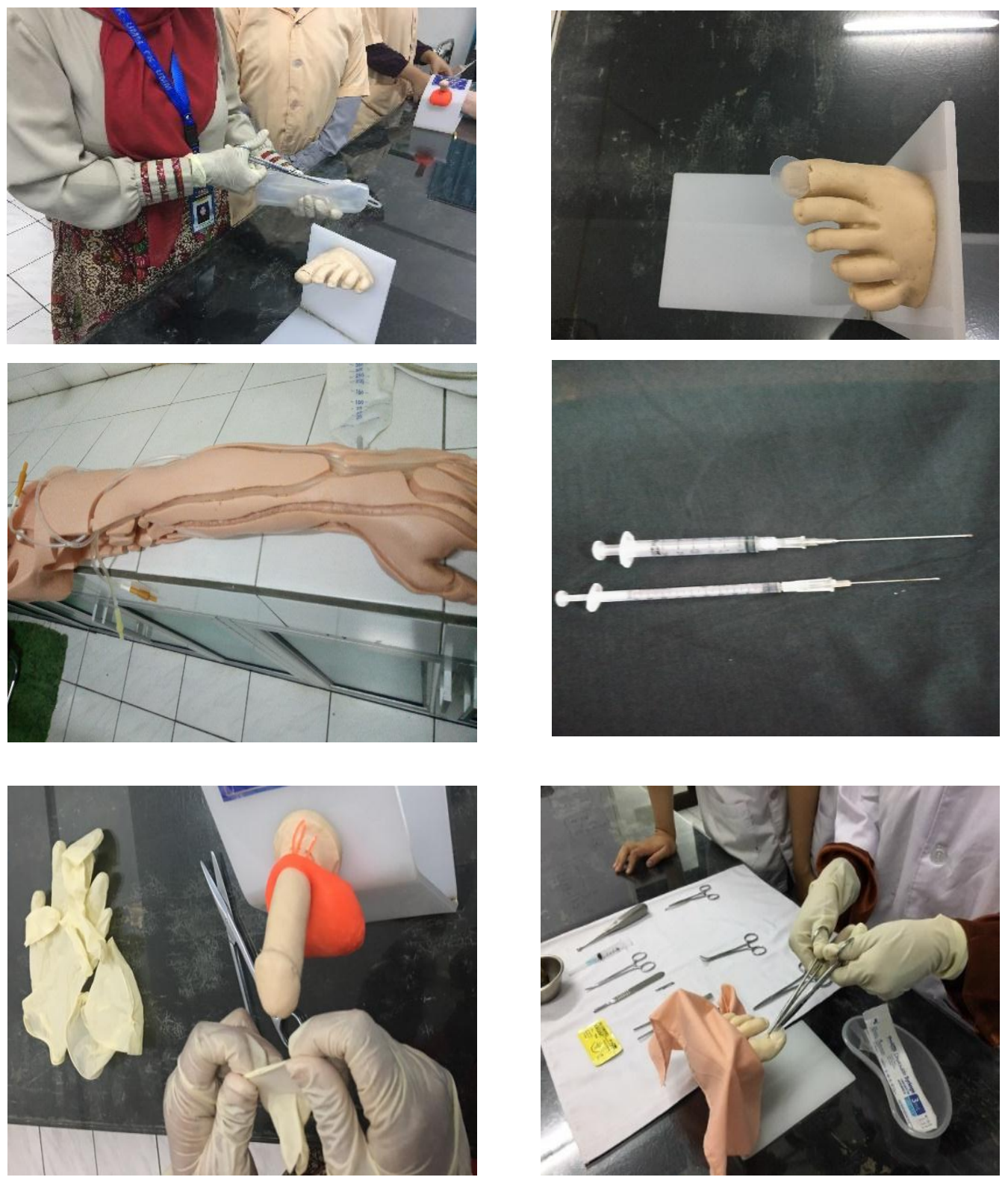

Gambar 2. Hasil modifikasi alat skill mandiri

Tujuan pembelajaran skills laboratorium adalah untuk menyamakan pembelajaran dan evaluasi ketrampilan klinik dengan menggunakan alat penilaian yang sama bagi semua mahasiswa, serta meningkatkan sikap mahasiswa dalam memberi pelayanan pada pasien (Mahmoud, 2016).

Nursalam (2009) menyatakan bahwa Pengalaman Belajar Praktikum merupakan proses pembelajaran di laboratorium dalam rangka memperkuat teori- teori pengetahuan yang didapatkan dengan cara pengalaman belajar lain. Strategi rancangan pembelajaran praktikum merupakan pengintegrasian antara teori pengetahuan dan keterampilan dasar profesional dengan menggunakan pendekatan model dan metode pembelajaran, sehingga pelaksanaan pembelajaran dikelola secara terintegrasi. 
Zaenal dan Nasution menjelaskan bahwa (2011) menjelaskan bahwa pelaksanaan pendidikan, evaluasi pembejaran memiliki beberapa tujuan antara lain untuk mengetahui efektivitas metode pembelajaran dan memperoleh masukan atau umpan balik bagi instruktur dan siswa dalam rangka perbaikan atau evaluasi. Kurangnya sarana pembelajaran juga menjadi hambatan yang dialami oleh mahasiswa. Faktor ini termasuk mencakup ketersediaan alat, bahan, dan sarana multi media seperti video untuk pelatihan keterampilan sangat penting untuk mendapatkan pengalaman belajar yang optimal. Tanpa peralatan yang memadai proses belajar pada skill lab tidak dapat dilakukan secara optimal untuk mencapai tujuan pembelajaran atau kompetensi yang diharapkan, karena pada intinya model dan peralatan tersebut yang membedakan proses pembelajaran skill lab dengan perkuliahan ataupun dengan tahap klinis dengan pasien. Studi lain juga menyebutkan bahwa adanya peralatan yang memadai yang didukung oleh instruksi dan media pembelajaran

Skill mandiri sangat membantu praktikan dalam menyiapkan ujian OSCE akhir Blok. OSCE merupakan metode penilaian yang didasarkan dalam pengujian yang obyektif. Karena pertanyaan dan penilaan atas jawaban diberikan secara baku dihadapan penguji. OSCE dapat menilai kompetensi klinik para mahasiswa secara komprehensif dan terstandart (Zayyan M.,2011) OSCE memerlukan alat dan bahan habis pakai yang tidak sedikit, karena mahasiswa harus menggunakan alat peraga yang dilengkapi bahan habis pakai. Sehingga tidak sedikit sampah bahan habis pakai yang dihasilkan. Dari banyaknya bahan habis pakai ini dimanfaatkan sebagai alat modifikasi skill mandiri mahasiswa. Seperti yang sudah kita lakukan selama ini bahan habis pakai gloves yang selesai digunakan ujian OSCE dapat kita manfaatkan sebagai modifikasi bahan preputium di manikin sirkumsisi karena glove menyerupai lapisan kulit pada manikin hecting. Dapat juga kita modifikasi sebagai drainase pada manikin luka atau tumor. Botol plastik infus dimodifikasi menyerupai kuku manusia kita gunakan untuk skill ekstraksi kuku. Selang infus (IV Line) dapat kita modifikasi sebagai pembuluh darah pada manikin, ini digunakan untuk skill vena seksi pada manikin infus. Jarum abocart (neddle) digunakan untuk NGT atau biasanya di sebut sonde untuk hewan coba, yang di manfaatkan oleh Laboratorium Farmakologi. Karet selang infus digunakan sebagai bola karet tabung LED pada praktikum Patologi Klinik.

Dari hasil modifikasi bahan habis pakai yang sudah di buat tersebut harapannya adalah untuk mengurangi sampah bahan habis pakai non infeksius yang ada di Laboratorium Skills Lab. Selain itu dapat dimanfaatkan oleh mahasiswa sebagai skill mandiri dalam persiapan OSCE akhir Blok, sehingga akan meningkatkan hasil ujian OSCE akhir blok yang dilaksanakan oleh mahasiswa. Ini dibuktikan bahwa praktikan yang melaksanakan praktikum mandiri sangat terbantu dengan adanya alat-alat modifikasi bahan habis pakai non infeksius yang kita sediakan untuk skill mandiri.

Penggunaan alat modifikasi sebagai media belajar klinik sederhana menyerupai alat atau manikin sebenarnya sangat membantu mahasiswa dalam skill mandiri. Keuntungan sebagai alat peraga modifikasi mudah didapat dan mirip dengan asli serta mudah penggunaan serta perawatananya. Sudah barang tentu mengurangi unit cost pembiayaan skill mandiri di Laboratorium Ketrampilan Klinik . Harapannya semua mahasiswa mempunyai kesempatan untuk melakukan praktek skill mandiri. Sehingga mahasiswa akan lebih terampil dalam menguasai materi skill pada semua blok-blok di Laboratorium Ketrampilan Klinik. Selain itu mahasiswa mampu meningkatkan professional, percaya diri, serta motiasi pada pasien nantinya pada waktu proses klinik 

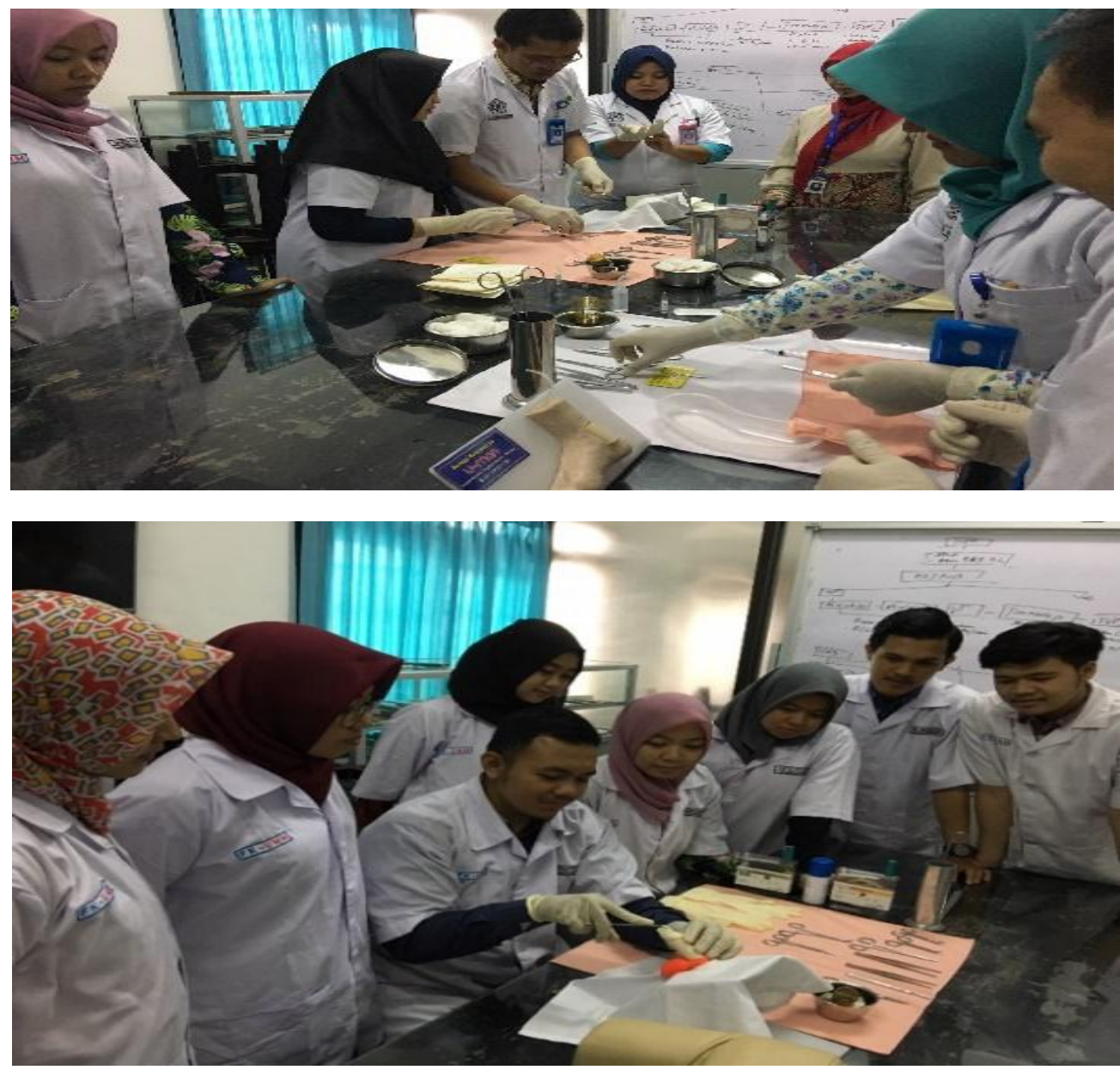

Gambar 3 Pelaksanaan praktkum mandiri

\section{KESIMPULAN}

Skill mandiri sangat membantu praktikan dalam menyiapkan ujian OSCE akhir Blok. OSCE merupakan metode penilaian yang didasarkan dalam pengujian yang obyektif. Karena pertanyaan dan penilaan atas jawaban diberikan secara baku dihadapan penguji. OSCE dapat menilai kompetensi klinik para mahasiswa secara komprehensif dan terstandart.

Penggunaan alat modifikasi sebagai media belajar klinik sederhana menyerupai alat atau manikin sangat membantu mahasiswa dalam skill mandiri. Keuntungan sebagai alat peraga modifikasi mudah didapat dan mirip dengan asli serta mudah penggunaan serta perawatananya. Sudah barang tentu mengurangi unit cost pembiayaan skill mandiri di Laboratorium Ketrampilan Klinik . Harapannya semua mahasiswa mempunyai kesempatan untuk melakukan praktek skill mandiri. Sehingga mahasiswa akan lebih terampil dalam menguasai materi skill pada semua blok-blok di Laboratorium Ketrampilan Klinik. Selain itu mahasiswa mampu meningkatkan professional, percaya diri, serta motiasi pada pasien nantinya pada waktu proses klinik 


\section{UCAPAN TERIMA KASIH}

Ucapkan terimakasih diucapkan kepada Kepada Dekan Fakultas Kedokteran Universitas Muhammadiyah Malang (Dr.dr. Meddy Setiawan.,SpPD.,FINASIM) yang selalu memberi dukungan kepada kami dan kepada Ka. Lab Ketrampilan Klinik FK UMM (dr. DN Pravitasari.,SpKK) \& Ka. Lab Biomedik FK UMM (dr. Anung Putri Illahika.,M.Si) yang selalu mensuport dan dorongannya kepada tenaga kependidikan di lingkungan FK UMM

\section{DAFTAR PUSTAKA}

Hardisman., Y. (2013). Pandangan Mahasiswa Terhadap Hambatan pada pelaksanaan Skills Lab di Fakultas Kedokteran Andalas. Jurnal Pendidikan kedokteran Indonesia, 180-187.

Setiawan, F. E. (2017). Pengantar Metodelogi Penelitian. Malang: Zifatama jawara

Mahmoud. (2006). Clinical skills Lab. Fakulty of Medicine Suez Canal University

Nurini. (2002). Skills lab. Yogyakarta. Yogyakarta: Medica FK UGM

Zayyan M. Objective Strukture Clinical examination. The assessment of choice OMJ. 2011.26 (4):219-22

Zainuddin,M., 2001. Mengajar-Praktikum. PAU-PPAI Universitas Terbuka. Jakarta 